\title{
鉄系圧粉体の焼結時の寸法变化におよぼす黒鉛の特性の影響
}

\author{
高田 仁輔江 1 ，河合 伸泰纺2

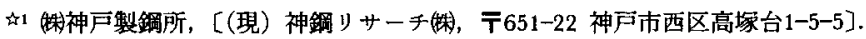

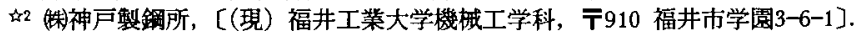

\section{Effect of Graphite Properties on Dimensional Change of Fe-Based Powder Compacts during Sintering}

\author{
Jinsuke Takata ${ }^{\hat{\alpha} 1}$ and Nobuyasu Kawai ${ }^{\hat{\kappa} 2}$ \\ \$1 Kobe Steel Ltd., [Present Address: Shinko Research Ltd., 1-5-5 Takatsukadai Nishi-ku, Kobe 651-22.]. \\ औ2 Kobe Steel Ltd., [Present Address: Department of Mechanical Engineering, Fukui Institute of Technology, \\ 3-6-1 Gakuen Fukui 910].
}

Received August 31, 1995

\section{SYNOPSIS}

The effect of graphite properties on the dimensional change of Fe-2mass\% $\mathrm{Cu}-0.8$ mass\%C-0.75mass\% zinc stearate was examined by using two kinds of natural graphite, flaky graphite of $0.5-35 \mu \mathrm{m}$ and amorphous graphite of 3-9 $\mu \mathrm{m}$. The compacts were sintered in endogas. Their sintering behaviors were correlated with the properties of graphite.

As the size of graphite decreased, the compacts shrank and the dimensional change varied according to $0.27 \log (B / A) \%$ when graphite was replaced from $A$ to $B \mu \mathrm{m}$. Finely divided flaky graphite showed a rapid carburization, which led to the acceleration of sintering and the suppression of copper growth. When flaky graphite was divided to $0.5 \mu \mathrm{m}$, however, the dimensional change did not obey above formula at all. In this case, the compact expanded at the temperature ranging from about 150 to $450^{\circ} \mathrm{C}$ and the carburizing rate markedly decreased above $970^{\circ} \mathrm{C}$, with a large fraction of the graphite remaining after sintering. Amorphous graphite of $9 \mu \mathrm{m}$ also showed a similar expansion in the early sintering stage, but the carburizing rate did not decrease. Such behaviors led to a remarkable shrinkage by liquid generation due to the ternary monotecto-eutectic reaction above the melting point of copper.

KEY WORDS

dimensional change, iron based powder, graphite, sintering, carburization.

\section{1 緒 言}

鉄系焼結品の特性の向上をはかる上で，黒鉛は最も 効果的で廉価な副原料の 1 つである. 機械的性質と黒 鉛の特性との関係については, 不純物である随伴鉱物 の浸炭速度 ${ }^{1 \prime}$, 疲労強度や衝撃值 ${ }^{2-3)}$ への影暗, 粒度 の強度への影響 4)，種々の炭素粉の粉末治金用原料 としての適用性 ${ }^{5)}$, 低合金鋼粉での添加成分と黒鉛と
の界面現象上での問題8. 1などの報告がある.

一方, 黒鈶は焼結過程での寸法変化への影響も顕著 で，その制御には黒鉖の量 ${ }^{8-10)}$ だけでなく，等級の 変化による対応が経験的におこなわれているが,これ に関する報告は見当たらない。

ところで，天然黒鉛は鱗片状，鱗状，土状に分類さ れ,一般に前二者が結晶質黒鈶, 後者が無定形黒鉛上 
呼ばれている ${ }^{11)}$ ，粉末冶金用には鱗片状(Flaky)を用 い, 変成岩中に数mass\% 程度存在する.これを浮遊選 鉱の後，水と捕集剂である灯油の入ったボールミルに より湿式粉砕精練し，さらに酸やアルカリによる化学 処理で随伴鉱物を除去して純度を上げることもある.

土状(Amorphous）も脈理をなした鱗片状や鱗状に比べ て，結晶が小さいだけで結晶棈造をもつ．原石は土塊 状で85mass X 程度の炭素分をもち，同様に精練される。

本稿では， $\mathrm{Fe}-\mathrm{Cu}$-C-ステアリン酸亜鈶系の焼結にお ける寸法変化挙動の解明の一環として ${ }^{12-16)}$, 鱗片状 黒鉊を主体に土状黒鈆の影響についても検討した。

\section{2 実験方法}

\section{1 実験条件}

実験方法は既報とほぼ同様で, 使用した粉末は水ア トマイズ鉄粉（神戸製鋼製，300M），電解銅粉（福田 金属䈃粉工業製，CE20)，黒鉛粉およびステアリン酸 亜鉻粉（日東化成製，Zn-st 之省略）である.

Table 1 にA-H粉の鱗片状黑鉛と $\mathrm{X}$, Y 粉の土状黒 鉛の特性を示す．鉄系焼結品に用いられる鱗片状黒鉛 は，一般に数一 10 数 $\mu \mathrm{m}$ であるが，特に粒度の影響を 検討するために極端な粒径のものまで準備した．最小 は特殊塗料用の平均粒径 $0.5 \mu \mathrm{m} の \mathrm{~A}$ 粉で, 比表面積 と揮発分が最高で，また最大はCu系焼結品において潤 滑性能向上の目的で用いられる35 $\mu \mathrm{m}$ のH粉である. 灰分は化学処理した G粉が最低で，C粉が最高である. 土状黒鉛は鉛筆やゴム製造の原料が主とした用途であ る.これらはSouth Western 社製のC粉を除いて，い ずれも日本黒鈶工業製である.

配合は標準のFe-2mass\&Cu-0.8mass\%C-0.75mass\%Zn-st 系の外, $\mathrm{Fe}-3$ massXC系で黒鉛の浸炭性を検討した。

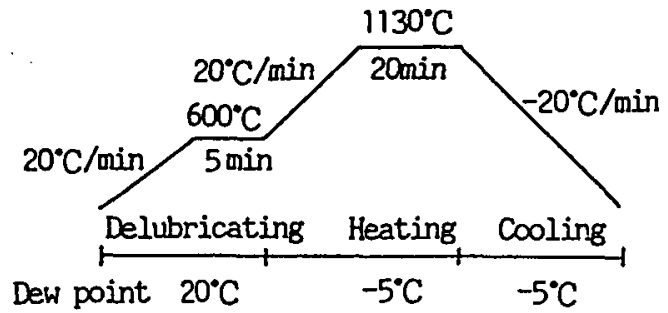

Fig. 1 Standard condition of sintering.

試験片は $490 \mathrm{MPa}$ で両押成形した $5 \times 5 \times 30 \mathrm{~mm}$ の圧粉体で, 寸法変化は加圧方向に対し直角方向の長さ $30 \mathrm{~mm}$ 対象 に，多機能型熱膨張計 ${ }^{171}$ または，焼結途中で冷却し た試験片をマイクロメータで測定した。

焼結条件は, 標準配合の試験片には吸熱型ガス(32.0

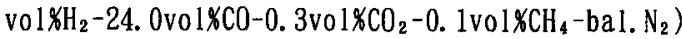
に準じた混合ガスの雾囲気下で, Fig. 1 に示す露点お よびヒートパターンでおこなった，他の配合の場合は 高純度Ar中で， $-35{ }^{\circ} \mathrm{C}$ の露点で実施した.

焼結挙動は熱膨張測定や急冷試験片の結合 $\mathrm{C}$ 量から 検討すると共に，黒鉛の特性としては黒鉛化度および 熱天秤による重量变化を調べた。

\section{2 黒鉛化度の測定}

黒鉛化度の測定には幾つかのモデルがあるが，ここ ではFranklinの方法 ${ }^{18)}$ を用いた。これは炭素の六方 網平面の積み重なりは，秩序ある黒鉛的積み重なりの 部分と，無秩序な積み重なりの乱層構造の部分との混 じたものと仮定している．後者の未黒鉛化部分が全体 に対して占める割合を $p$ とすると，X線回折により観 察される $(00 \ell)$ 回折線から測定される面間隔 $\mathrm{d}_{(002)}$ $(\mathrm{nm})$ との間に式(1)の関係があり, 黒鈶化度は1-p で表 される.

$$
d_{(002)}=0.3440-0.0086\left(1-p^{2}\right)
$$

Table 1 Properties of natural graphite powders.

\begin{tabular}{|c|c|c|c|c|c|c|}
\hline Kind & Powder & Grade & $\begin{array}{l}\text { Mean particle size } \\
\mu \mathrm{m}\end{array}$ & $\begin{array}{l}\text { Specific surface }{ }^{* 3} \\
\mathrm{~m}^{2} / \mathrm{g}\end{array}$ & $\begin{array}{l}\text { Ash content } \\
\text { mass } \%\end{array}$ & $\begin{array}{l}\text { Volatile matter } \\
\text { mass\% }\end{array}$ \\
\hline Flaky & $\begin{array}{l}A \\
B \\
C \\
D \\
E \\
F \\
G \\
H\end{array}$ & $\begin{array}{l}\text { USSP } \\
\text { CPM-4 } \\
\text { SW1651 } \\
\text { UCP } \\
\text { CPN } \\
\text { CPB } \\
\text { ACP } \\
\text { CB-150 }\end{array}$ & $\begin{array}{l}0.5 * 2 \\
4 \\
5 \\
6 \\
8 \\
10 \\
12 \\
35\end{array}$ & $\begin{array}{l}370 \\
13.7 \\
11.3 \\
14.1 \\
10.7 \\
7.9 \\
9.1 \\
6.1\end{array}$ & $\begin{array}{l}0.8 \\
1.5 \\
3.9 \\
1.4 \\
1.1 \\
1.5 \\
0.5 \\
0.7\end{array}$ & $\begin{array}{l}4.0 \\
0.8 \\
1.1 \\
0.7 \\
0.3 \\
0.4 \\
0.5 \\
0.2\end{array}$ \\
\hline Amorphous & is $\begin{array}{l}X \\
Y\end{array}$ & $\begin{array}{l}\text { APB } \\
\text { GA-150 }\end{array}$ & $\begin{array}{l}3 \\
9\end{array}$ & $\begin{array}{r}11.5 \\
8.0\end{array}$ & $\begin{array}{l}1.3 \\
1.4\end{array}$ & $\begin{array}{l}2.1 \\
2.1\end{array}$ \\
\hline
\end{tabular}

*1 Sedimentation analysis,

*2 SEM observation,

*3 BET method 


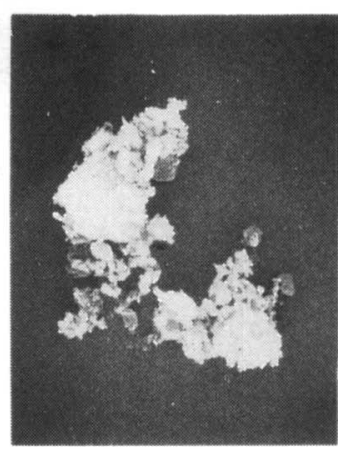

Powder A

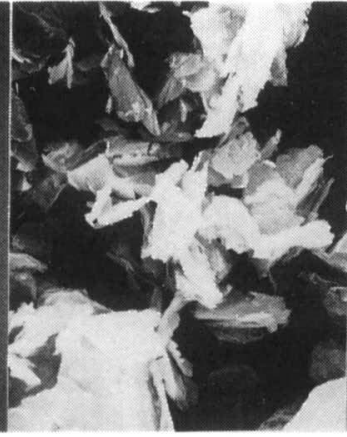

Powder B

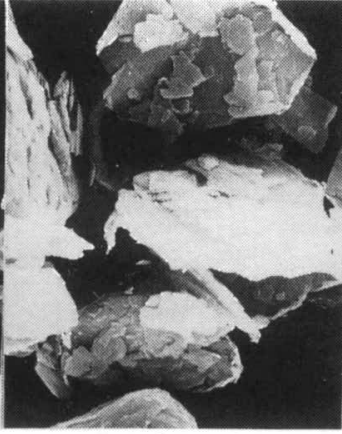

Powder F

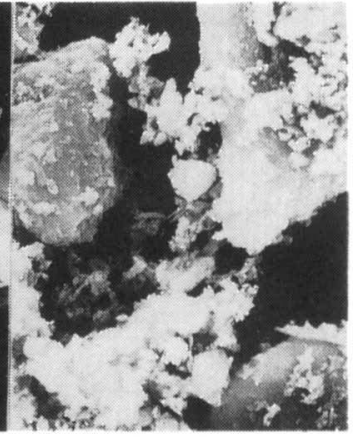

Powder Y

Photo.1 Scanning electron micrographs of graphite powders. $\quad \overleftarrow{10 \mu \mathrm{m}}$

\section{3 結 果}

\section{1 黒鉛の特性}

走查型顕微鏡による黒鉛の外観をPhoto. 1 に示す. 鱗片状黒鉛は $\mathrm{F}$ 粉で見られるように特有の六角板状を もち, その網平面から層状に剝離する.これは黒鉛結 晶において強い共有結合である網平面内の炭素原子間 の結合に比べ, 網平面間はファンデァワールス結合の ため, 粉砕により平面上の剝離が優先する. しかし, 粉砕が進むとA粉のように, 平面の破壊も同時に進行 して粒状となり凝集し易くなる.

一方，Y粉は鱗片状のような自形をもたず，塊状と 微粉が混在する. 鱗片状では閵滑性を有する網平面が 圧粉体密度の向上にも寄与するが, $0.5 \mu \mathrm{m}$ まで微粉 化したり, 土状黒鉛ではこの効果は期待できない.

黒鉛のX線回折結果をFig. 2 に示す. D粉では鋭い 回折線を示し, 六方晶の外, 粉砕によって生じた菱面 体晶 ${ }^{19)}$ も観察される. A 粉では結晶粒の微細化に伴 うピーク高さの減少, 拡幅化が進むことにより回折線 の重複が目立つようになり, また, 低角度側では無定 形特有のバックグランドの上昇が現れる. 一方，Y粉 も同様のパターンを示すが, 回折線はむしろA粉より 明確である.

標準Siによる回折線図形の補正後のD, AおよびY 粉の $(002)$ 線の面間隔は, 各 $0.3363 ， 0.3378 ， 0.3373$ $\mathrm{nm}$ で，黒鉛化度は各 $0.86 ， 0.65 ， 0.71$ となり，A粉は 粉砕により無定形化が進行し，土状よりも低下した。

黒鉛 $2 \mathrm{~g}$ を $\mathrm{H}_{2}$ 中, $10^{\circ} \mathrm{C} / \mathrm{min}$ で昇温した時の熱天秤の結 果をFig. 3 に示す. F 粉は約 $250^{\circ} \mathrm{C}$ 以降ほぼ直線的に

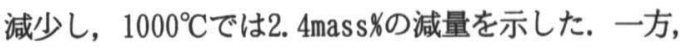
$\mathrm{A}$ 粉と $\mathrm{Y}$ 粉は $100^{\circ} \mathrm{C}$ 付近から減少し始め, 前者の方が 勾配が大である. 途中で僅かな勾配の変化があるもの

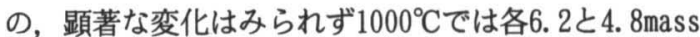

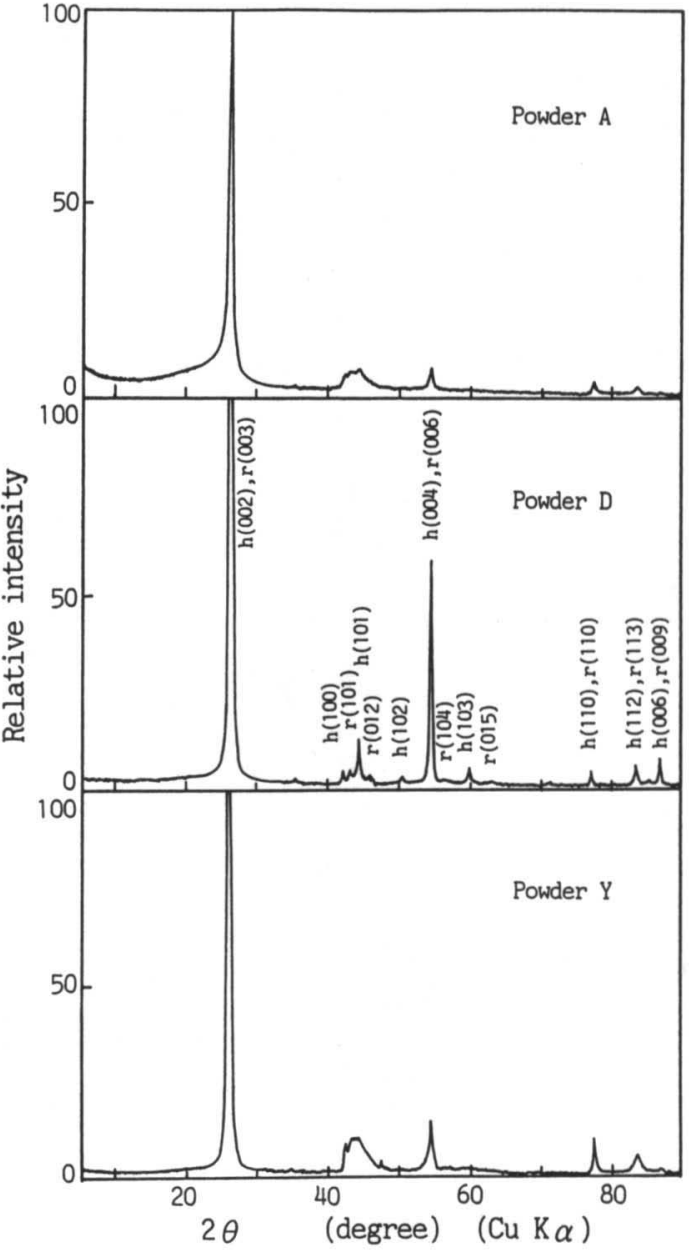

Fig. 2 X-ray diffraction patterns of graphite powders.

$\mathrm{h}$ : hexagonal, $\mathrm{r}$ : rhombohedral

\& の減量を示した. これらの值はTable 1 の揮発分よ りも高いが, 三者の傾向は一致する. なお，揮発分は， 黒鉛粉を入れた蓋付き磁性るつぼをさらに黒鉛るつぼ に入れ, 大気中 $850^{\circ} \mathrm{C} て ゙ 7 \mathrm{~min}$ 間急熱して測定した. 


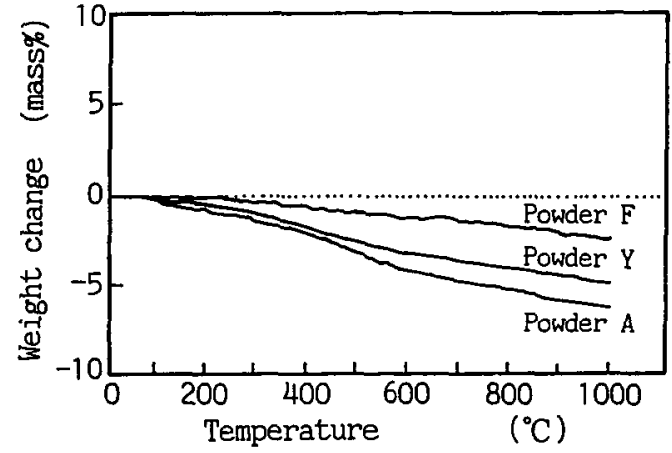

Fig.3 Thermogravimetric curves of graphite powders heated at $10^{\circ} \mathrm{C} / \mathrm{min}$ in $\mathrm{H}_{2}$. Sample weight: $2 \mathrm{~g}$

\section{2 寸法変化}

標準条件で圧粉体の寸法変化におよぼす黒鉛の粒径 あるいは比表面積の影響をFig. 4 に示す. 直線から著 しく外れた $0.5 \mu \mathrm{m} の A$ 粉を除いて, 寸法は粒径の減 少または比表面積の増加と共に収縮する，この関係は Table 1 での灰分, 黒鉛の種類が異なってもほぼ成立 する. 実線によると黒鉛の粒径を Aから B $\mu \mathrm{m}$ への変 更した時, 寸法変化の变化量\% は式(2)で求められる.

$\Delta$ D. $C .=0.27 \log (B / A)$

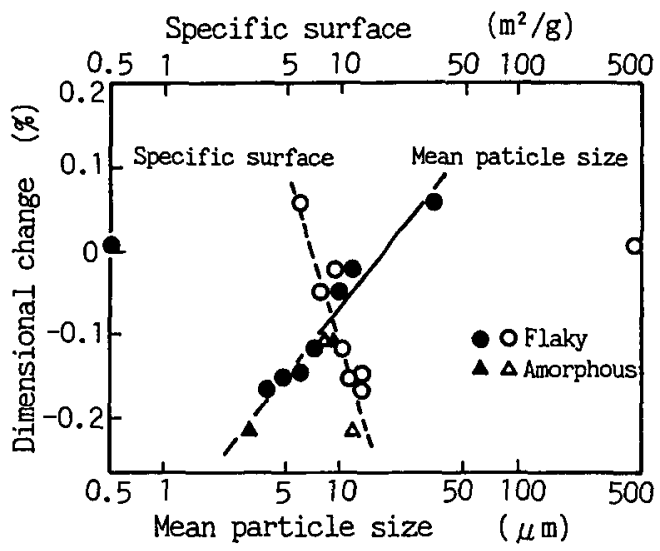

Fig. 4 Infuence of graphite powders on dimensional change of compacts after sintering.

\section{3 熱膨張挙動}

標準条件下における主な熱膨張曲線をFig. 5 に示す. 先ず，曲線 1 - 3 はFig. 4における両端と中央の $4 ， 10$, $35 \mu \mathrm{m}$ の鱗片状黒鈶である. 既報では $\mathrm{G}$ 粉について述 べてきたが，上記もほぼ同一結果なので，ここでは簡 単に曲線 2 のF粉について説明する. 約 $120^{\circ} \mathrm{C}$ 点 で閵滑阂の溶融による小さな膨張があり, b 点の 500 ${ }^{\circ} \mathrm{C}$ 付近から雾囲気浸炭による膨張, 約 $720^{\circ} \mathrm{C} の \mathrm{c}$ 点で の $A_{1}$ 変態による収縮を経て,$\gamma-\mathrm{Fe}$ 域の d点から黒鉛
の浸炭による膨張, $1083^{\circ} \mathrm{C}$ Cu融点の e 点からの銅膨 張, $f$ 点からの恒温加熱での収縮, $g$ 点付近で雾囲気 からの復炭, h点から $\gamma \rightarrow \alpha$ 変態が起こる.

粒径の影響が顕著に出るのは d点で， B, F, H粉 の各々は約 $915 ， 940 ， 960^{\circ} \mathrm{C}$ と粒径の増大にしたがい 高温側にずれると共に，d 点以降の勾配および膨張量 は隇少し浸炭は遅延する.この結果，e 点からの銅膨 張は粒径が大きいほど増大し，また，冷却過程の g点 から起こる復炭による勾配の緩慢の程度屯著しくなる。 一方，A粉とY粉は曲線 4，5のように，曲線 1 3とはかなり異なったパターンを示すが，これは焼結 初期から始まる膨張に起因する．両者とも $150^{\circ} \mathrm{C}$ 付近

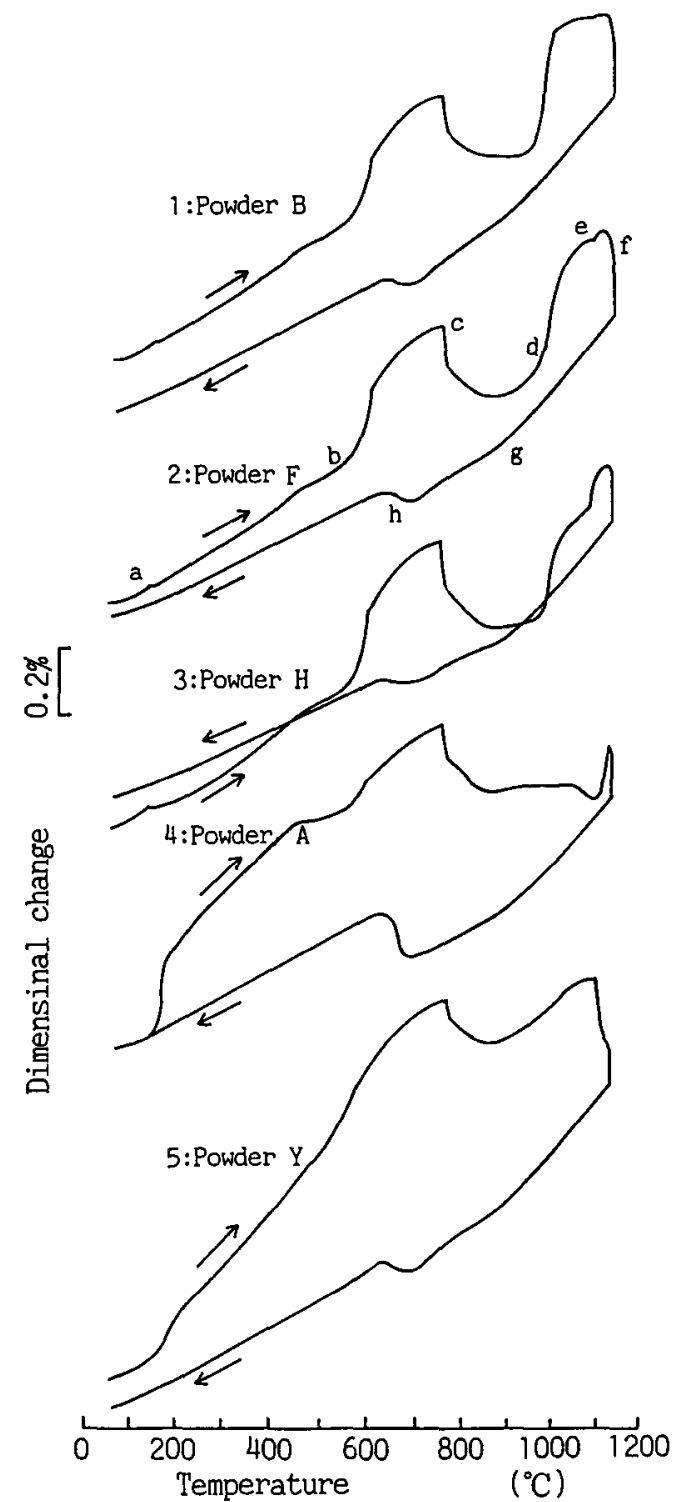

Fig.5 Dilatometric curves under standard conditions. 
から急に立ち上った後，ゆるやかな膨張を続け，前者 は約 $450^{\circ} \mathrm{C}$ から収縮の傾向を示す，また，Cu融点では 前者の鋭い膨張に対し，後者は著しく収縮する.

\section{4 寸法変化と浸炭挙動}

焼結中における寸法变化の推移を，浸炭の観点から 検討する. Fig. 6 は標準条件での焼結の途中から, $\mathrm{Ar}$ 気流中へ引出し徐冷した試験片の結果である.

Fig. 6aはB B F粉の結果で，僅かにずれた軌跡を示 す. 先ず, $700^{\circ} \mathrm{C}$ までの結合 $\mathrm{C}$ 量の増加と膨張は，雾 囲気からの浸炭により鉄粉表面に生成した $\mathrm{Fe}_{3} \mathrm{C}$ (セメ ンタイト）の微粒子によるものである ${ }^{13)}$ ．それを過 ぎると $A_{1}$ 変態での $\alpha-\mathrm{Fe}+\mathrm{Fe}_{3} \mathrm{C} \rightarrow \gamma-\mathrm{Fe}$ による $\mathrm{Fe}_{3} \mathrm{C}$
Peへの固溶や，焼結の開始により著しく収縮する．A 変態を越えると鉄粉粒子の内部も一様に $\gamma-\mathrm{Fe}$ となり， 黒鉛による浸炭が急速に進んで膨張すると同時に，焼 結による収縮も促進される. 結合 $\mathrm{C}$ 量は $1090^{\circ} \mathrm{C}$ で最高 となり, 以降恒温加熱中に脱炭と収縮が起こり, 冷却 過程で復炭した.

黒鉛の粒径の影響は，浸炭，寸法変化の両挙動之も 微粉の方が常に先行する形で現れ，B粉では $1020^{\circ} \mathrm{C}$ ら収縮に入るのに対し, $\mathrm{F}$ 粉は $1060^{\circ} \mathrm{C}$ を越えてから起 こり，この差が焼結後まで持続する．このように微粉 ほど焼結が促進され，C剅張が抑制され，見掛け上黒 鉛添加量の增加と類似の挙動となる.

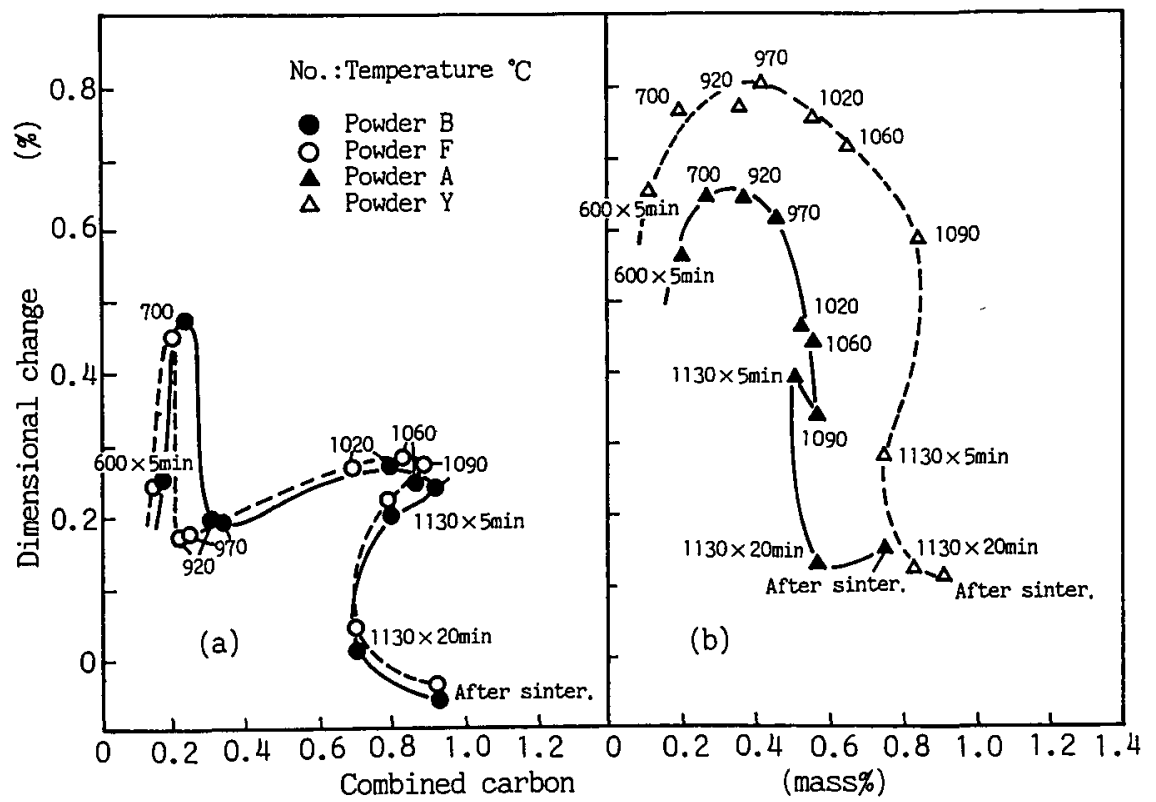

Fig.6 Relation between combined carbon and dimensional change of compact cooled from each temperature under standard condition.

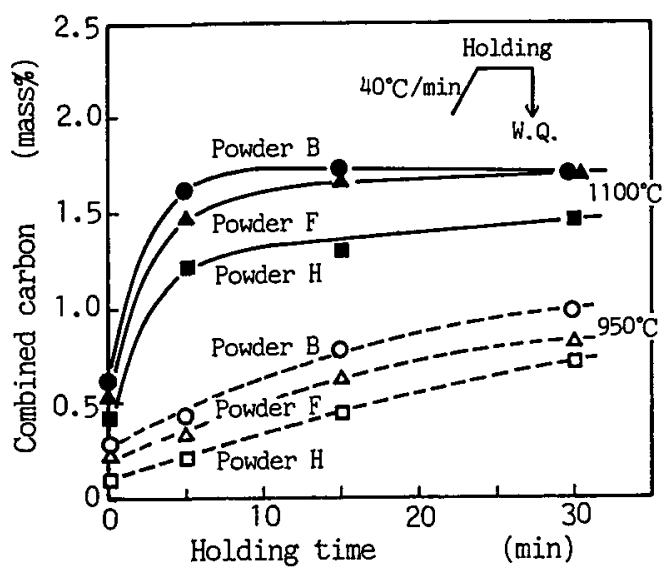

Fig. 7 Carburizing behavior of $\mathrm{Fe}-3 \mathrm{C}$ compacts sintered in $\mathrm{Ar}$.

焼結初期少ら膨張し たA粉とY粉の結果を Fig.6bに示すが，曲線 の形態はFig. 6aと比べ かなり異なる. 両者と も $600^{\circ} \mathrm{C} \times 5 \mathrm{~min}$ では， Fig. 6aの倍以上膨張す るが, $700^{\circ} \mathrm{C} へ の$ 膨張 は小さい.また，920 ${ }^{\circ} \mathrm{C}$ へかけては全く収縮 しないが，極大値とな るA粉の $920^{\circ} \mathrm{C}, \mathrm{Y}$ 粉 の $970^{\circ} \mathrm{C}$ 過ぎると収 縮する一方となる.こ れは初期膨張による鉄 粉同志の接点の減少と, $\alpha \rightarrow \gamma$ 変態での収縮に よる接点の回復が, 焼 結の遅延と促進に関与 したものと考えられる. 結合 $\mathrm{C}$ 量の推移は $\mathrm{A}$ 粉では, $970^{\circ} \mathrm{C}$ 以降で急速に停 滞し， $1090^{\circ} \mathrm{C}$ まで間に 0.11 mass しか増加せず， B， F 粉の0.58，0.62mass\% に比べはるかに少ない。この

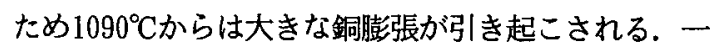
方， Y粉での浸炭は $\mathrm{B} ， \mathrm{~F}$ 粉より遅いが， $\mathrm{A}$ 粉のよう な停滞がなく，1090 Cからは著しく収縮する，A，B， $\mathrm{F}, \mathrm{Y}$ 粉の焼結後の残留黒鈶量は $0.29,0.02,0.01$, 0.05mass\%で，A粉だけが多量の黒鉛を残留した.

\section{5 黒鉛の鉄粉への固溶挙動}

$\gamma-\mathrm{Fe}$ 域の2，3の温度における鱗片状黒鉊の固溶挙 動を調べる. 各温度でのCの固溶限以上の黒鉛を添加 したFe-3massXC系をAr中で $40^{\circ} \mathrm{C} / \mathrm{min}$ で昇温し, 所定時 
間保持後，水冷した試験片の結合Cの結果をFig. 7 に 示す. $\gamma$ 領域に入ってから所定温度到達までに加熱温 度 $950^{\circ} \mathrm{C}$ 場合で約 $1 \mathrm{~min}, 1100^{\circ} \mathrm{Cで}$ 約 $5 \mathrm{~min}$ 要するた めに保持時間 Omin ですでに浸炭が進行しているが, いずれの温度でも微粉ほど浸炭が進む．950 우゙は30

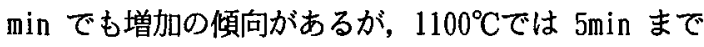
に一気に進行し，微粉ほど短時間に飽和する。より大 きな粒径の関係についても同傾向の報告がある ${ }^{20)}$.

\section{4 考察}

特異な焼結挙動を示すY粉とA粉について考察する. 先ず,Fig. 6bにおいてY粉は $1090^{\circ} \mathrm{C}$ からは著しく収 縮するが, これはFe-Cu- $\mathrm{Fe}_{3} \mathrm{C}$ 擬 3 元系の偏共晶反応 ${ }^{10}$. 12)で生じた融液による液相焼結に起因している.

Tabeshfar ら ${ }^{211}$ は液相が粒界と微細気孔に浸透する 際の駆動力，濡れによるエネルギー損失を計算し，粒 界での液相厚さと微細気孔の半径が同じオーダーであ れば，液相Cuは後者に優先的に浸透することを示して いる. Y粉では焼結初期の膨張によりFe粒子間隙が拡 大し，また浸炭む十分に進行してしているので溶融Cu は濡れにくくなるため，毛管現象によって粒界に浸透 できずに微細気孔に存在し，擬 3 元系の偏共晶反応を 引き起こしたものと考えられる. 同様の現象は圧粉体 密度が低い場合でも生じた ${ }^{22) 。}$

つぎに，A粉を用いた場合に生じる約 150 から 450 ${ }^{\circ} \mathrm{C}$ までの膨張と， $970^{\circ} \mathrm{C}$ 以降で生じる浸炭速度の著し い低下の原因について，黒鉛の特性との関連で述べる. 鉄系圧粉体の熱膨張測定で現れる膨張は，鉄粉自体 の線膨張や変態を除くと, 合金元素の鉄粉への拡散, 化合物の生成，毛管現象による融体の鉄粉粒界への浸 透, 気体発生による内圧の上昇, などにより引き起こ される.このうち焼結初期のこのような低い温度で起 こる可能性のあるものは, 融体の浸透と気体の発生で あるが, 前者はFig. 5 の曲線 1-3にみられるように Zn-st の溶融では小さな膨張を示すだけであるので, 後者が原因と思われる。

この時点での気体の発生源の 1 つとして, 黒鈶と吸 熱ガス中の $\mathrm{CO}_{2}, \mathrm{H}_{2} \mathrm{O}$ おび $\mathrm{H}_{2}$ との反応を考虑した場合, 前二者は既報 ${ }^{13)}$ でも述べたように低温では進行せず， また, 後者む $\mathrm{CH}_{4}$ の生成により気体のモル数が半減す るので，いずれも内圧上昇の原因とはなり得ない. 気体発生源の他の 1 つには黒銛の揮発分が考えられ, Fig. 3 での $100^{\circ} \mathrm{C}$ 付近からの重量減少が対象になる. 黒木ら ${ }^{23)}$ はステアリン酸カルシウムを潤滑剤に用い
たときに起こる約 $430^{\circ} \mathrm{C}$ 著しい膨張は, 潤滑剤の分 解, 蒸発のガスの流出を, 高粘性の融液が妨害したこ とによる内圧の上昇であるとしている，Zn-stも同様 のことが考えられるが，この分解，蒸発は初期膨張上 りも高温の約 $300-400^{\circ} \mathrm{C}^{13)}$ で起こるので, 気体発生 源とはなり得ない.しかし， $450^{\circ} \mathrm{C}$ 付近からの収縮は この融液の消隇と関連があるのかも知れない。

ところで，黒鉿の揮発分はTable 1 における鱗片状 黒鉛のように，粒径が小さくなるにしたがい増える傾 向にあり，石炭などのように内蔵している揮発分とは かなり異質のものと予想される. 先述したように，黒 鉛の湿式粉砕工程では灯油が使用されているが，その 付着分は大気中 $500-600^{\circ} \mathrm{C}$ で加熱除去され，揮発分上 しては残存しないとされている.

一方, 黒鉛は強い酸化剂溶液中で湿式酸化された場合, 0 やH は =0, OH, $\mathrm{COOH}$ などの基として炭素に結合し た酸化黒鉛( 黒鉛酸) を生じ，これは熱的に非常に不 安定な物質で, $150^{\circ} \mathrm{C}$ 以上で $\mathrm{CO}_{2}, \mathrm{CO}, \mathrm{O}_{2}$ などを放出 して分解することが知られている24)，衝撃粉砕がお こなわれた $\mathrm{A}$ 粉では，揮発分が急増していることから 類似の化合物が生成しているか，または，黒鈆の活性 点へのガスの吸着が推察されるが明らかでない.

黒鉛の反応は固体表面の至る所で均一に進行するの ではなく，活性点と呼ばれる表面の特殊な点において 進行するものとされている. 人造黒鉛の高温酸化は黒 鈶化度の低い部分が活性点になり，また黒鉊単結晶で も端面(edge plane)が活性点となり, 基底面( basal plane)よりも反応速度が高(25)．Bacon ${ }^{20)}$ は人造黒 鉻をボールミルで長時間粉砕すると，黒鉛構造の割合 が減少して，無定形炭素に近づくことを述べており， A粉の場合もFig. 2 でも示したように，同様の現象之 考えられる．黒鉛化度が低下し，また，微粉のため端 面も増加し，鉄粉との接触点も増えているので浸炭速 度の増大が予想される. 実際, Fig. 6bでのA粉の 970 ${ }^{\circ} \mathrm{C}$ まで浸炭速度は, Fig. 6aのBおよびF粉に比べて 大であるが，それ以降で著しく低下している.

この急低下の原因としては，黒鉛の酸化と分散状態 が考えられ，いずれも鉄粉との接触界面の問題である. 吸熱型ガスは既報 ${ }^{13)}$ でも示したように，高温になる に伴い酸化性となる．活性点が多いA粉はそれだけ酸 化速度も大きいと考えられるが, 焼結後には多量の黒 鉛が残留しているので, 量的な減少が浸炭減速の直接 の原因になるほどの酸化は生じていない，したがって 活性点が酸素に吸着され，鉄粉との接触が蚄害された 
271ことも考えられる.

一方, 三浦ら ${ }^{5)}$ は超微粉のカーボンブラックを添加し た圧粉体では，鉄粉粒子表面を均一に覆うというより む，むしろ鉄粉粒子間隙に凝集した形で存在する場合 が多いと報告している. Photo.1 で示したようにA粉 も凝集し易く，同様の状況にあったとすると，焼結前 半には接触面積の大きな均一被䧗粉が急速に鉄粉に固 溶消隇し，その後は接触面積の小さな凝集粉だけとな ったと考えられる.

以上のように，初期膨張および浸炭速度の低下には， 黒鉛の微粉化に伴う活性点の増加が関与していること む推察される.

\section{4 結 論}

Fe-2mass\%Cu-0. 8mass\%C - 0.75 mass\%2n-st系の焼結時 の寸法変化におよぼす黒鉛の影響を調查した．実験は 吸熱型ガスの雾囲気下で, 平均粒子径0.5-35 $\mu \mathrm{m}$ の鱗 片状黒鉛を主体に，3-9 $\mu \mathrm{m}$ の土状黒鉛についても検 討した.

（1）黒鉛の微粉化に伴い寸法は収縮し, 粒径AからB $\mu \mathrm{m}$ への変更により, 寸法変化は $0.27 \log (\mathrm{B} / \mathrm{A})$ xだけ 変わるが, $0.5 \mu \mathrm{m}$ の鱗片状はこの関係に従わない.

（2）鱗片状黒鉛の微粉化は, 浸炭速度の向上により焼 結の促進，銅膨張の抑制に作用する.しかし， 0.5 $\mu \mathrm{m}$ の場合は $150^{\circ} \mathrm{C}$ 付近から膨張が起こり, $970^{\circ} \mathrm{C}$ 以 上で浸炭速度が著しく低下する.

（3） $0.5 \mu \mathrm{m}$ 䚬片状黒鉊による焼結初期で起こるこの膨 張は, $100^{\circ} \mathrm{C}$ 付近から発生する黒鈶の揮発分の離脱 が, 内圧の増大に関与したものと考えられる. また， この揮発分の増加および浸炭速度の低下は, 微粉化 による黒鈆の活性点の増加に起因すると推察される.

（4）寸法变化の制御には，従来から用いられている鱗 片状黒鉛の数 -10 数 $\mu \mathrm{m}$ が適当である. 一方, 土状 黒鉛は焼結過程で膨張，収縮の程度が顕著であるた め, 寸法の安定性の上で問題が残る.

\section{文献}

1) N. Dautzenberg, J.Hewing: Powder Metall. Int., 25 (1977) 16.

2) G. T. Brown, P. K. Jones: Int. J. Powder Metall., 6 (1970) 29.

3) B. E. Perkins: Metals Australia, (1971) June 105.

4) K. Feneberger, A. R. Feichtiger: Metal Powder
Report, 39 (1984) 157.

5）三浦秀士，本田忠敏，徳永洋一 : 粉体および粉末 治金, 36 （1989）357.

6）高田仁輔：粉体粉末冶金協会，秋季大会講演概要 集,（1991） 104.

7) J. Takata, H. Takigawa, S. Okamoto, T. Matsushita T. Hanaoka: Advances in Powder Metal lurgy \& Particulate Materials, MPIF, 5 (1992) 251.

8) S. T. Rothman, N. L. Peterson, C. M. Watten, L. S. Nowick: J. Appl. Physics, 39 (1968) 5041.

9) T. Krantz: Int. J. Powder Metall., 5 (1969) 35.

10）三谷裕康, 真島一彦, 花立有功, 日本金属学会誌, 39 (1975) 168.

11）粉体工業会: 粉体工学便覧, 日刊工業新聞社発行, (1990) 849.

12）高田仁輔，河合伸泰：粉体および粉末冶金， 41 （1994） 1150.

13）高田仁輔，河合伸泰：粉体および粉末治金， 41 (1994) 1157.

14）高田仁輔，河合伸泰：粉体および粉末冶金， 41 (1994) 1553.

15）高田仁輔，河合伸泰：粉体および粉末冶金， 42 （1995） 827.

16）高田仁輔，河合伸泰：粉体および粉末冶金, 42 （1995） 1430.

17）高田仁輔，河合伸泰：粉体および粉末冶金, 41 (1994) 1012.

18) R. E. Franklin: Acta Cryst., 4 (1951) 235.

19) H. P. Boehm, R.W. Conghl in: Carbon, 2 (1964) 1.

20) V.A. Dymchenko, Yu. F. Morozov: Perspect ives in Powder Metallurgy, MPIF, 3 (1968) 295.

21) K. Tabeshfar, G. A. Chandwick: Int. Powder Metall. Conference, Florence-Italy, (1982) 693.

22）高田仁輔：粉体粉末冶金協会，秋季大会講演概要 集,（1988）146.

23）黒木英憲：粉体および粉末治金，33（1986） 187.

24) G. R. Hennig, Progress in Inorganic Chemistry, Interscience, 1 (1959) 138.

25) G. R. Hennig: Chemistry and Physics of Carbon, Marcel Dekker, 2 (1966) 1.

26) G. E. Bacon: Acta Cryst., 5 (1952) 392.

27) P. Ulf. Gummeson : Perspectives in Powder Metallurgy, MPIF, 3 (1968) 304. 